\title{
Does fiscal consolidation promote economic growth and employment? Evidence from the PIIGGS countries
}

\author{
Philip Arestis* \\ Cambridge University, UK \\ Ayşe Kaya** \\ Izmir Katip Çelebi University, TURKEY \\ Hüseyin Şen*** \\ Ankara Yıldırım Beyazıt University, TURKEY
}

Using annual data over the period 1980-2014, this paper attempts to provide an answer to the question of whether fiscal consolidation promotes growth and employment in the context of the PIIGGS countries (Portugal, Ireland, Italy, Greece, Great Britain, and Spain) by using the Bootstrap Granger causality analysis proposed by Kónya (2006) that allows testing for causality on each individual country separately, and by accounting for dependence across countries. Our findings indicate that in no country considered fiscal consolidation does promote growth. However, fiscal consolidation negatively affects employment in Portugal and Italy whereas it positively influences employment in Great Britain. Based on our findings, we may suggest that the effects of fiscal consolidation on employment produce mixed results, varying with country to country.

Keywords: Fiscal consolidation, growth, employment, PIIGGS countries, panel Granger causality analysis

Jel codes: $C 23, E 62, H 50, H 62$

\section{INTRODUCTION}

Fiscal consolidation has received new attention especially so in the aftermath of the substantial rise in government budget deficits and debt ratios of many countries, which resulted from the Great Financial Crisis of 2007/09. ${ }^{1}$ The term typically called for in many economies, regardless of advanced and emerging ones, to reduce high public debt ratios and rebuild fiscal buffers used during the crisis. ${ }^{2}$ Increases in government budget deficits and debt-to-GDP ratios for many countries have resulted partly from sharp rises in government spending and transfers, and partly from poor tax receipts during the crisis.

\footnotetext{
Acknowledgements: Ayşe Kaya gratefully acknowledges that she received financial assistance from TUBITAK (The Scientific and Technological Research Council of Turkey) under BIDEB-2219 project during her study at Cambridge University. Additionally, authors wish to thank the editor of EJEEP and anonymous referees for their helpful comments and suggestions. Responsibility for any error and/or omission which may remain rests solely with the authors.

* Cambridge University, Department of Land Economy, 19 Silver Street, Cambridge, CB3 9EP, UK. E-mail: pa267@ cam.ac.uk

** Corresponding Author: Izmir Katip Çelebi University, Faculty of Economics and Administrative Sciences, Public Finance Department, Izmir, Turkey. E-mail: ayse.kaya@ikc.edu.tr

*** Ankara Yıldırım Beyazıt University, Faculty of Political Sciences, Public Finance Department, Esenboğa Külliyesi, Ankara, Turkey. E-mail: hsen@ybu.edu.tr

${ }^{1}$ The consensus among the major countries of the Group of 20 (G-20) in the wake of the Great Financial Crisis, and the subsequent Great Recession, that propelled them to announce co-ordinated stimulus packages quickly disappeared with the first signs of a tepid recovery. Following the 2010 Toronto Summit of the G20 leaders, many countries, especially in Europe, committed to fiscal consolidation in response to these concerns in the form of time-bound and targeted reductions in the structural budget deficit (Chowdhury and Islam, 2012).

${ }^{2}$ See IMF (2014).
} 
Sharp increases in government spending are worrisome due to the fact that increases in government spending are followed by increases in taxes. Higher distortionary taxes may then dampen economic growth and employment in the long run (Cogan et al., 2013). With the outburst of the crisis, many countries have experienced large reductions in their growth rates. As a result of this, a low rate of economic growth caused higher unemployment. Especially in the case of the PIIGGS countries (Portugal, Ireland, Italy, Greece, Great Britain, and Spain); these countries have experienced a worrying decrease in growth along with rising unemployment.

As the deficits and the increase in debt persisted for a long time, the problem was structural rather than cyclical. Because this trend was unsustainable, many countries attempted to reduce their budget deficits by means of fiscal contractions. Consequently, the PIIGGS countries have embarked on a process of implementing fiscal consolidation to provide and maintain fiscal sustainability, with the hope of promoting growth and employment. In this regard, deepening the understanding of the macroeconomic consequences of fiscal consolidation is an important issue to analyze comprehensively.

The objective of this contribution is to make a contribution to the current fiscal consolidation literature from a different perspective. To this end, the paper seeks to analyze whether fiscal consolidation creates the Keynesian, non-Keynesian or weak Keynesian effect by employing a relatively new econometric technique, at least in the context of fiscal consolidation literature; this is Kónya's (2006) Bootstrap Granger causality analysis. More specifically, the paper attempts to provide an answer to the question of whether fiscal consolidation promotes growth and employment in the context of the PIIGGS countries. The reason for why we consider employment as a second key variable, alongside growth in our analysis, is that without regard to developed or developing countries, unemployment is a major socio-economic problem for all countries, which they may always face. Despite varying with country to country, growth may not always assure employment. To put it in a different way, increases in the employment capacity of an economy may not always be accompanied with increases in its growth rates. In other words, growth may not generate employment for jobless people, what is called 'growth without employment'. Such type of growth is not the desired one especially for those countries, which face a growing unemployment rate. In short, the expectation from a fiscal consolidation, at least theoretically, is that it should promote both growth and employment, and we, therefore, propose to consider in our analysis not only growth but also employment.

We believe this paper makes important contributions to the existing fiscal consolidation literature, as follows. We first unearth the possible existence of one-way and/or two-way causalities between fiscal consolidation and economic growth or between fiscal consolidation and employment within the context of a recently-used bootstrap causality technique, as alluded to above. Additionally, due to the existence of the multi-dimensional definition of fiscal consolidation, the two different definitions are utilized to capture these various aspects of fiscal consolidation in this paper. In so doing, we utilize the fiscal consolidation first proposed by Alesina and Ardagna (1998), which is based on the change in the primary cyclically adjusted budget balance and also the IMF's (Devries et al., 2011), the so-called 'policy action-based' approach. Our contribution to the literature is by means of the cross-checking of two alternative methods of fiscal consolidation so as to confirm the robustness of the overall analysis. Finally, the paper considers the PIIGGS economies as the case study. As it is known, they have undertaken comprehensive fiscal stabilization programs soon after the Great Financial Crisis of 2007/2009, which affected these countries. They have hitherto encountered huge budget deficits and government debt burdens due to generous fiscal stimulus packages that were put into practice to rescue bankrupt companies as 
well as to provide the life-line support to their economies, in order to help those countries to overcome the great recession. However, after 2010, they abandoned expansionary fiscal policies. Instead, they proceeded to implement contractionary fiscal policies, i.e. fiscal consolidation.

The rest of the paper is organized as follows: Section 2 outlines the theoretical debates that relate to fiscal consolidation. Section 3 presents the related empirical literature, while Section 4 describes methodology and data. Section 5 describes empirical results and then discusses some economic and policy implications. Finally, Section 6 summarizes and concludes the paper.

\section{THEORETICAL DEBATES RELATED TO FISCAL CONSOLIDATION}

The debate on fiscal consolidation stems from the conventional Keynesian wisdom that argues that fiscal austerity ${ }^{3}$ has a contractionary effect on economic activity. ${ }^{4}$ According to this proposition, cuts in government spending and tax hikes that imply contractionary fiscal policy, adversely affect aggregate demand and therefore output through the fiscal multiplier mechanism. More clearly, the conventional Keynesian view asserts that fiscal consolidation, at least in the short run, triggers an adverse effect on aggregate demand and thus on growth and employment through either government spending cuts and/or tax hikes, or both. The multiplier effects of fiscal consolidation aggravate the initial demand drag on the economy (Kolev and Matthes, 2013).

Contractionary fiscal policy can either be caused directly by a reduction in public consumption or investment or indirectly by the fall in private consumption -brought about by higher taxes or lower transfers to households. In line with this, the so-called accelerator mechanism suggests that changes in investment, as a response to a fall in output, amplify the effect of any change in private consumption or government spending on aggregate demand (Escudero and Mourelo, 2017). However, in the early 1990s, the standard Keynesian proposition was challenged by Giavazzi and Pagano (1990), who asserted that fiscal consolidation could create an expansionary effect on both growth and employment not only in the long run but also in the short run. ${ }^{5}$ They demonstrated in their study that by considering the case of Ireland in 1987-89 and in Denmark in 1983-86 in terms of how the large consolidations were associated with large consumption and investment booms in these economies. With a sharp contrast to the traditional wisdom, their findings indicated that during the years of fiscal consolidation, the growth rate increased and unemployment decreased in these two countries. ${ }^{6}$ This expansionary effect of fiscal consolidation based on Giavazzi and Pagano (1990) is termed as 'expansionary fiscal contractions' in the literature. $^{7,8}$

\footnotetext{
${ }^{3}$ The terms 'fiscal austerity', 'fiscal consolidation', 'fiscal contraction' and 'fiscal adjustment' are used interchangeably through this paper.

${ }^{4}$ Obviously, fiscal consolidation carries a negative direct demand effect in the short run. However, the question of how strong the net short-run effect on growth is, and perhaps even its sign, is uncertain (Baxter and King, 1993).

${ }^{5}$ As far as we know, the 'expansionary fiscal contractions hypothesis' was firstly proposed by Feldstein (1982) and then repeated by Giavazzi and Pagano (1990) and his followers.

${ }^{6}$ Apart from Giavazzi and Pagano (1990), there is a vast literature arguing for the possibility that fiscal consolidation is not harmful, and might indeed result in a boost to economic growth in the short-run. Follow-up studies, such as Giavazzi and Pagano (1996), Alesina and Perotti (1995, 1997), Alesina and Ardagna (1998, 2010), Giavazzi et al. (2000), Ardagna (2004), Hernández de Cos and Moral-Benito (2013) appear to be in a consensus that fiscal consolidation is not always self-defeating. Additionally, several theoretical justifications of its non-Keynesian effects have been offered in the literature (see, for instance, Coenen et al., 2008; Almeida et al., 2011).

${ }^{7}$ See Giavazzi and Pagano (1990), Perotti (1998).

8 According to the expansionary fiscal contraction view, benign effects of fiscal consolidation rely on the perceived persistence of public spending cuts. If government spending is expected to be permanently lower, then permanent income rises and the thereby induced rise in private consumption may outweigh the depressing effects of elementary Keynesian multiplier mechanics. If, however, government spending cuts are not long-run credible, then the latter effects dominate and hence Keynesian results emerge. For further details, see Lucke (1999).
} 
Unlike the conventional Keynesian view, the Giavazzi and Pagano's (1990) expansionary fiscal contractions hypothesis relies on a more optimistic viewpoint regarding fiscal consolidation. According to proponents of non-Keynesian effects of fiscal consolidation, the negative aggregate demand effects emanating from fiscal consolidation can be compensated by the non-Keynesian effects of fiscal consolidation that emerge from various channels. First of all, fiscal consolidation efforts mean reductions in government deficits and government's debt burden. It is highly likely that reductions in the both improve expectations with regard to debt sustainability as well as enhance government credibility with regard to its ability and willingness to reduce fiscal deficits and debts further, compelling real interest rates to fall. Secondly, falling interest rates can create crowding-in effects on private investment as well as wealth effects on consumption ${ }^{9}$, which could outweigh negative Keynesian demand effects. Thirdly, fiscal consolidation efforts not only do they improve the general confidence of economic actors but also increase their propensity to spend or invest more. ${ }^{10}$

The theoretical arguments of this challenging view of the Keynesian position on this matter are based on the standard neo-classical view. Neo-classical proponents of fiscal consolidation are grounded on their arguments and concerns about the effectiveness of fiscal policy - and the need to focus on debt/deficit management- can also be rationalized in terms of three propositions: the 'Ricardian equivalence theorem', the 'crowding out' and 'market confidence'. The 'Ricardian equivalence theorem' maintains that public sector profligacy may be fully offset by private sector prudence since economic agents correctly anticipate that future tax liabilities will rise as a result of fiscal expansion. It then follows that the contractionary consequences of a fiscal retrenchment will be balanced by an increase in private sector spending as 'fully rational' economic agents correctly anticipate a decline in future tax liabilities. The crowding out thesis maintains that fiscal expansions lead to a rise in real interest rates thus inducing a decline in private sector spending because of its sensitivity to higher costs of borrowing. The strong version of this thesis suggests that the decline in private sector spending will exceed the increase in aggregate demand, induced by the increase in government expenditure. It follows that, under such circumstances, fiscal austerity can boost growth by stimulating private sector spending. Finally, the least theoretically grounded, but the most influential view is that fiscal austerity now is necessary because it will provide market confidence that lies at the core of private sector spending decisions. One should also note that the advocates of the market confidence thesis overlook the fact that rating agencies typically include growth variables in their assessment of sovereign risk analysis. More importantly, studies have shown that the impact of a growth contraction on measures of sovereign risks is higher than the impact of debts and deficits on such risks. Hence, when fiscal consolidation leads to growth contractions they reduce rather than raise market confidence (Verick and Islam, 2010; Chowdhury and Islam, 2012).

Fiscal consolidation measures are worthwhile if they have growth and employment promoting effects or, at the very least, they do not lead to a net decline in aggregate demand. There are thus various channels through which a fiscal consolidation program can either reach its goal without imposing any output or employment loss or, even better, be accompanied by growth and employment creation. These propositions, despite the theoretical problems with them (see, for example, Arestis and Sawyer, 1998; Arestis, 2011, 2012), ultimately need to be also empirically investigated. Here, the evidence does not support the propositions of the advocates of fiscal

\footnotetext{
${ }^{9}$ Wealth effect on consumption explains the effects of reduction of tax burdens of individuals on their consumption resulted from fiscal consolidation. Accordingly, reduction in tax burden of individuals means an increase in incomes of them. Increases in income led by reduction in taxes stimulate private consumption by depending on marginal propensity to consume.

${ }^{10}$ For further explanations, see Alesina et al., 1998; Bhattacharya and Mukherjee, 2013; Kolev and Matthes, 2013.
} 
consolidation. There is hardly any evidence that fiscal policy multipliers are either zero -as in the case of full Ricardian equivalence- or negative -as in the strong version of the crowding out thesis. Even some of the proponents of fiscal consolidation agree that the available evidence suggests that fiscal policy has significant effects on output and employment and those effects are likely to be larger during recessions (Islam and Chowdhury, 2010).

\section{REVIEW OF THE EMPIRICAL LITERATURE}

The empirical testing of the effects of fiscal consolidation on macroeconomic variables has received great concern throughout last decade. This concern has shown itself recently in a number of studies for many specific country or country groups. Following-up the studies by Giavazzi and Pagano (1990), several studies such as Alesina and Perotti (1995, 1997), Giavazzi and Pagano (1996), and Alesina and Ardagna (1998) have addressed the issue.

In reviewing the existing literature, we observe that there are a substantially large but still growing number of empirical studies on fiscal consolidation. Considering the current literature, the existing studies can be classified under three main tendencies. In this regard, several studies, including Ramey and Shapiro (1998), Blanchard and Perotti (2002), Alesina et al. (2002), Barro and Redlick (2009), Hall (2009), Ramey (2009), and Romer and Romer (2010), take fiscal consolidation into account as part of a broader literature on the effects of fiscal policy and/or expansionary effects of fiscal policy; whereas some others, such as Heylen and Everaert (2000), Giudice et al. (2004), and Afonso et al. (2006), examine the conditions for successful fiscal consolidations with an idea that they bring about a significant reduction in the debt burden of countries. Another stream of the literature attempts is to find out what the most effective fiscal policy instruments are for successful fiscal consolidation.

Large parts of the studies mentioned above, tend to confirm that expenditure cut-based adjustment programmes are more effective than that of tax hike-based ones in both boosting confidence and output (see Alesina and Perotti, 1995, 1997, 1998; Giavazzi and Pagano, 1996; McDermott and Wescott, 1996; Perotti, 1998; Alesina and Ardagna, 1998; Afonso et al., 2006; Giudice et al., 2007; Alesina and Ardagna, 2010, 2013; Afonso and Jalles, 2012; Hernández de Cos and MoralBenito, 2013, among others). However, it is worth mentioning that there are few studies, such as Briotti (2002), Baldacci et al. (2004), and Mati and Thornton (2008), which reveal opposite results.

The study by Alesina and Perotti (1996) is interesting in that it suggests that expenditure-based fiscal consolidation has been more successful than revenue-based one, so far as debt reduction is concerned - fiscal adjustments through spending cuts on transfers and government wage bill to that by tax increases. Dermott and Wescott (1996) focused on 74 cases of fiscal consolidation in 20 industrialized countries over the period 1970-1995. They find that 14 country cases were successful in the sense that they were marked by a sustainable reduction in the debt-to-GDP ratio as well as an increase in growth and employment creation. In this regard, Gupta et al. (2005) draw attention to the size of the fiscal adjustment, which is crucial for fiscal sustainability in particular for countries with high initial fiscal deficits. Based on their empirical findings, they go further in that expenditure-based adjustments lead to lasting fiscal consolidations, while revenue-based programs are short-lived. A follow-up study by Alesina and Ardagna (2009) explored 107 episodes of fiscal consolidation in the OECD countries during the period 1970-2007. They found that out of 107 episodes, 27 episodes could be classified as cases that combined fiscal consolidation with growth. Along similar lines, Alesina and Ardagna (2010) analyzed fiscal 
consolidation episodes in the OECD countries for the period 1970-2007. They concluded that 21 OECD countries could be classified as cases that combined fiscal consolidation with growth.

Afonso and Jalles (2012) re-visited the so-called expansionary fiscal adjustment using alternative measures of fiscal episodes. According to their results, the change in the cyclically adjusted primary balance contributed positively to the success of a fiscal consolidation. The share of the consolidation that took place via the spending side of the budget had almost always a positive estimated coefficient but it was never statistically significant. On the other hand, if a fiscal consolidation was based largely on the revenue side, it reduced the corresponding probability of success.

Moreover, the study by Hernández de Cos and Moral-Benito (2013) found that in order to succeed in reducing debt levels, economic growth was the factor. On the other hand, cuts in public wages were the key ingredient of fiscal consolidations in which persistent reductions in primary budget deficits were achieved. Arin et al. (2015) start with dataset used by Arin et al. (2011) and re-estimate the determinants of successful fiscal consolidations, using semi-parametric methods. Their results show that the more governments rely on cutting expenditures, the more likely that they succeed in their consolidation attempts.

Nevertheless, so far, there is no general consensus in the literature on the relationship between fiscal consolidation, economic growth, and employment. As for the fiscal consolidation, growth and employment relations, the existing literature on this matter is indeed scarce. On the one hand, the fiscal consolidation literature contains some empirical studies linking fiscal consolidation with growth and/or employment but they are very few (see, for instance, Blanchard and Perotti, 2002; Giordano et al., 2007; Cimadomo and Bénassy-Quéré, 2012). The empirical findings of these studies reveal that positive shocks on government spending stimulate output at least in the short run. With regard to taxes, they found that positive shocks on taxes suppress output (see especially, Blanchard and Perotti, 2002; Cimadomo and Bénassy-Quéré, 2012).

On the other hand, most empirical studies on the impact of fiscal consolidation focus on output, and only just few of these studies look at the employment case (see Monacelli et al., 2010; Brückner and Pappa, 2012; Turrini, 2013; Banerjee and Zampolli, 2016; and, Escudero and Mourelo, 2017). One can reach this firm judgment shortly after a quick review of the current empirical works on the issue. For example, Monacelli et al. (2010) estimate a negative but significant impact of government spending on unemployment and job creation. Brïckner and Pappa (2012) estimate structural VARs for a number of OECD countries and show that government spending can actually raise employment and unemployment at the same time, due to the fact that it also increases participation. A recent study by Turrini (2013) estimates the impact of fiscal consolidation on unemployment across EU countries, using a recent database of consolidation episodes built on the basis of a 'narrative' approach of Devries et al. (2011). The empirical results produced by Turrini (2013) show that the effect of fiscal consolidation on cyclical unemployment is significant but temporary for government spending-based measures. Escudero and Mourelo (2017) contribute to the existing literature by assessing quantitatively the short-term impact on job creation of changes in the expenditure and revenue composition during the Great Recession to shed light on how to boost employment while preserving fiscal positions. The analysis is undertaken by ways of a pooled cross-country and time-series model based on 32 advanced countries during the crisis period of 2007-2011. The results show that a fiscally-neutral change in the expenditure and revenue composition of fiscal consolidation can boost job creation. 
Despite a vast number of studies attempting to test the effects of fiscal consolidation, the empirical findings have produced no clear-cut results. Hence, further empirical studies focusing on different country-economies with different econometric techniques, as in the case of this study, may help in better understanding the nature and underlying mechanisms of the fiscal consolidation issue in general and its effect on growth and employment in particular.

\section{METHODOLOGY AND DATA}

\subsection{Methodology}

In this paper, we employ the Bootstrap Granger Causality approach, proposed by Kónya (2006). The Kónya's (op. cit.) approach has three superiorities over the alternative panel causality approaches. ${ }^{11}$ First of all, this approach is based on a Seemingly Unrelated Regressions (SUR) estimation that allows us to take into account cross-sectional dependence across countries. Second, it does not require the joint hypothesis for all members of the panel because it is based on a Wald test with country-specific bootstrap critical values. Finally, it requires no pre-testing for panel unit roots or co-integrating relationships. Since country-specific bootstrap critical values are used in this approach, the model variables need not be stationary. The variables can be used in level form, regardless of their unit root and cointegration properties.

\subsubsection{Cross-sectional dependence and slope homogeneity}

Investigating Granger causality within panel data framework requires a careful treatment. The first issue in that respect is to control for a possible cross-sectional dependency across countries since a shock affecting one country may also affect other countries because of a high degree of globalization as well as of international trade and financial integration. The Monte Carlo experiment carried out by Pesaran (2006) emphasizes the importance of testing for the crosssectional dependence in a panel data study and also illustrates the substantial bias and size distortions when cross-sectional dependence is ignored. The second issue is to decide whether the slope coefficients are treated as homogenous and heterogeneous to impose the causality restriction on the estimated parameters. The causality from one variable to another variable by imposing the joint restriction for the panel is the strong null hypothesis (Granger, 2003); and the homogeneity assumption for the parameters is not able to capture heterogeneity due to country-specific characteristics (Breitung, 2005). ${ }^{12}$

\subsubsection{Panel causality test}

If there are cross-sectional dependency and heterogeneity across countries, the method utilized should account for these features. Kónya (2006) showed that this approach did not require any pre-testing for the panel unit root and cointegration. In addition, by imposing country-specific constraints, we could also identify which and how many countries have Granger causal relations between their fiscal consolidation episodes, economic growth, and employment.

The system to be estimated in the bootstrap panel causality approach can be formulated as follows:

\footnotetext{
${ }^{11}$ We refer the interested readers to Kónya (2006) for a comprehensive discussion regarding panel causality methods.

${ }^{12}$ See Appendix B for a detailed description of the cross-sectional dependence and slope homogeneity tests.
} 


$$
\begin{aligned}
& F C_{1, t}=\alpha_{1,1}+\sum_{i=1}^{l y_{1}} \beta_{1,1, i F C_{1, t-i}}+\sum_{i=1}^{l x_{1}} \delta_{1,1, i} E G_{1, t-i}+\varepsilon_{1,1, t} \\
& F C_{2, t}=\alpha_{1,2}+\sum_{i=1}^{l y_{1}} \beta_{1,2, i F C_{2, t-i}}+\sum_{i=1}^{l x_{1}} \delta_{1,2, i} E G_{2, t-i}+\varepsilon_{1,2, t} \\
& F C_{N, t}=\alpha_{1, N}+\sum_{i=1}^{l y_{1}} \beta_{1, N, i F C_{N, t-i}}+\sum_{i=1}^{l x_{1}} \delta_{1, N, i} E G_{N, t-i}+\varepsilon_{1, N, t} \\
& E G_{1, t}=\alpha_{2,1}+\sum_{i=1}^{l y_{2}} \beta_{2,1, i F C_{1, t-i}}+\sum_{i=1}^{l x_{2}} \delta_{2,1, i} E G_{1, t-i}+\varepsilon_{2,1, t} \\
& E G_{2, t}=\alpha_{2,2}+\sum_{i=1}^{l y_{2}} \beta_{2,2, i F C_{2, t-i}}+\sum_{i=1}^{l x_{2}} \delta_{2,2, i} E G_{2, t-i}+\varepsilon_{2,2, t} \\
& E G_{N, t}=\alpha_{2, N}+\sum_{i=1}^{l y_{2}} \beta_{2, N, i F C_{N, t-i}}+\sum_{i=1}^{l x_{2}} \delta_{2, N, i} E G_{N, t-i}+\varepsilon_{2, N, t}
\end{aligned}
$$

and

$$
\begin{aligned}
& F C_{1, t}=\alpha_{1,1}+\sum_{i=1}^{l y_{1}} \beta_{1,1, i F C_{1, t-i}}+\sum_{i=1}^{l x_{1}} \delta_{1,1, i} E M P_{1, t-i}+\varepsilon_{1,1, t} \\
& F C_{2, t}=\alpha_{1,2}+\sum_{i=1}^{l y_{1}} \beta_{1,2, i F C_{2, t-i}}+\sum_{i=1}^{l x_{1}} \delta_{1,2, i} E M P_{2, t-i}+\varepsilon_{1,2, t} \\
& F C_{N, t}=\alpha_{1, N}+\sum_{i=1}^{l y_{1}} \beta_{1, N, i F C_{N, t-i}}+\sum_{i=1}^{l x_{1}} \delta_{1, N, i} E M P_{N, t-i}+\varepsilon_{1, N, t} \\
& E M P_{1, t}=\alpha_{2,1}+\sum_{i=1}^{l y_{2}} \beta_{2,1, i F C_{1, t-i}}+\sum_{i=1}^{l x_{2}} \delta_{2,1, i} E M P_{1, t-i}+\varepsilon_{2,1, t} \\
& E M P_{2, t}=\alpha_{2,2}+\sum_{i=1}^{l y_{2}} \beta_{2,2, i F C_{2, t-i}}+\sum_{i=1}^{l x_{2}} \delta_{2,2, i} E M P_{2, t-i}+\varepsilon_{2,2, t} \\
& E M P_{N, t}=\alpha_{2, N}+\sum_{i=1}^{l y_{2}} \beta_{2, N, i F C_{N, t-i}}+\sum_{i=1}^{l x_{2}} \delta_{2, N, i} E M P_{N, t-i}+\varepsilon_{2, N, t}
\end{aligned}
$$

where $\quad\left[F C_{1, t}, F C_{2, t}, \ldots, F C_{N, t}\right]^{\prime}, \quad\left[E G_{1, t}, E G_{2, t}, \ldots, E G_{N, t}\right]^{\prime}$ and $\quad\left[E M P_{1, t}\right.$, $\left.E M P_{2, t}, \ldots, E M P_{N, t}\right]^{\prime}$ denote the fiscal consolidation episodes (i.e. FC(AA), FC(IMF)), economic growth (EG) variable (i.e. real GDP), and employment rate (EMP), respectively. $l$ is the lag length, $i F C_{1}$ and $i E G_{1}$ are the maximal lags for $F C$ and $E G$ in the first set of equations, and $i F C_{2}$ and $i E G_{2}$ are the maximal lags for $\mathrm{FC}$ and $\mathrm{EG}$ in the second set of equations, and $\mathrm{N}$ is the number of the members in a panel $(j=1,2, \ldots, N)$. Since each equation in this system has different predetermined variables, while the error terms might be contemporaneously correlated (i.e. crosssectional dependency), these sets of equations are the SUR system. In the bootstrap panel causality approach, there are alternative causal relations to be found for a country: (i) there is oneway Granger causality from EG to $\mathrm{FC}$ if not all $\delta_{1 j, i^{s}}$ are zero, but all $\beta_{2, j, i^{s}}$ are zero; (ii) there is a one-way Granger causality running from FC to EG if all $\delta_{1 j, i}$ are zero, but not all $\beta_{2, j, i}$ are zero; 
(iii) there is a two-way Granger causality between EG and FC if neither $\delta_{1 j, i^{s}}$ nor $\beta_{2, j, i^{s}}$ are zero; and finally (iv) there is no Granger causality between EG and FC if all $\delta_{1 j, i^{s}}$ and $\beta_{2, j, i}$ are zero. The same causal relations can be established in terms of FC and EMP.

\subsection{Data}

In this paper, we use annual data. The data come from the following three sources: AMECO European Commission database, IMF's e-library as well as its WEO database. The study period of the paper spans from 1980 to 2014. The main reason for commencing data set from 1980 onwards is the availability of harmonized data for the countries under consideration.

We use three variables: fiscal consolidation episodes, GDP growth rate, and employment rate. One of the most important issues in examining the relationship between fiscal consolidation, economic growth, and employment is how to obtain a satisfactory empirical measure of fiscal episodes -either fiscal adjustments or expansions. This difficulty comes from the variety of definitions of fiscal consolidation episodes used in the literature. ${ }^{13}$ Still, how to determine a successful fiscal consolidation episode remains a non-consensual matter.

Despite that other criteria have been employed in the literature, ${ }^{14}$ we use two alternative definitions of successful fiscal consolidation:

(i) using the change in the cyclically adjusted primary budget balance (hereafter denoted by $\mathrm{CAPB}$ ) is at least 2 percentage points of GDP in 1 year or at least 1.5 percentage points on average in the last 2 years (e.g. Alesina and Ardagna, 1998); and

(ii) using the so-called policy action-based approach to account for consolidation episodes (e.g. Devries et al., 2011).

The percentage change in the CAPB-to-GDP ratio developed by Alesina and Ardagna (1998) is a widely used measurement method for fiscal consolidation episodes in the literature. This method is also the most commonly used approach in diagnosing fiscal episodes, which allow us to make the correction of the effects resulting from economic activity such as inflation or real interest rate changes. The CAPB measures adjust the budget data for changes in the macroeconomic environment and/or for the non-discretionary interest payments. Arguably, the cyclical adjustment is desirable as it makes it possible to filter out the discretionary effects of fiscal policy. However, the methods of calculation vary so greatly that it is doubtful whether cyclically-adjusted budget balance (hereafter denoted by $\mathrm{CAB}$ ) ratios are in fact suitable indicators for determining consolidation periods. Moreover, the data differs to a large extent depending on whether one uses IMF, EU or OECD data. Therefore, the reliability of the cyclically adjusted budget balance and CAPB data can be questioned (Wagschal and Wenzelburger, 2012). ${ }^{15}$

In addition to $\mathrm{CAPB}$ and $\mathrm{CAB}$ approaches that are widely used in the current literature, we also consider the policy action-based approach proposed by the IMF to identify fiscal episodes. ${ }^{16} \mathrm{By}$ doing so, we aim to cross-check two alternative definitions of fiscal consolidation episodes so that we can confer robustness to the overall analysis. In other words, we estimate the IMF's fiscal

\footnotetext{
${ }^{13}$ See Wagschal and Wenzelburger (2012) for a broader review of alternative definitions of fiscal consolidation.

${ }^{14}$ See Alesina and Perotti (1995), McDermott and Wescott (1996), Perotti (1999), and Lambertini and Tavares (2003).

${ }^{15}$ The IMF criticizes the existing literature for the use of cyclically adjusted budget balance (IMF, 2010: 96): 'The change in the CAPB-to-GDP ratio is an unreliable guide regarding the presence of fiscal consolidation. The standard approach tends to select periods associated with favorable outcomes but during which no austerity measures were actually taken. It also tends to omit cases of fiscal austerity with unfavorable outcomes.'

${ }^{16}$ For further details, see Devries et al. (2011).
} 
consolidation definitions (Devries et al., 2011) in addition to Alesina and Ardagna's (1998) definitions for the robustness checks.

We label fiscal consolidation episodes as FC(AA) and FC(IMF). ${ }^{17}$ The FC(AA) measure is the definition used by Alesina and Ardagna (1998) and the FC(IMF) measure follows IMF (Devries et al., 2011). The IMF's episodes are identified by looking at IMF and OECD historical reports and by checking what countries intended to do at the time of publication. The IMF's policy-action based approach uses descriptive historical facts to describe what happened to the deficit in a particular period.

We generate two dummy variables for all fiscal episode definitions -FC(AA) and FC(IMF)called 'fiscal consolidation episodes', which take the value of one when consolidation occurs and a value of zero otherwise. The IMF's fiscal consolidation dummy ${ }^{18}$ is defined following the narrative approach and focusing on policy actions -i.e. years in which the government implemented tax hikes or spending cuts to reduce the budget deficit regardless of the change in the CAPB.

The descriptive statistics for the variables used are provided in Table 1 of Appendix A. The figures presented in Table 1 indicate that, on average, the highest average GDP growth rate for the sample period is observed in Ireland as 4.30 per thousand. This country is followed by the other countries, Spain (2.23), Great Britain (2.15), Portugal (1.94), Italy (1.24), and Greece (0.89). In terms of the employment rate, Portugal has the highest average return (as 55.22 per thousand) among the sample countries. Portugal is tracked by Great Britain (52.29), Ireland (47.93), Greece (44.38), Spain (43.93), and Italy (42.82), respectively. Greece, Portugal, Great Britain, Ireland, Italy, and Spain are ordered for an average return of Alesina and Ardagna's (1998) fiscal consolidation episode. Turning to IMF's fiscal consolidation episode, it shows that Spain, Italy, Great Britain, Ireland, and Portugal are ordered for average return, respectively. At the same time, it is difficult to point out remarkable differences for both fiscal consolidation episodes across countries during the study period, 1980-2014.

\section{EMPIRICAL RESULTS AND DISCUSSION}

Before considering panel data causality, it is pretty important to investigate the characteristics of cross-sectional dependency and slope heterogeneity among countries under consideration. If a cross-sectional dependency exists among the countries, it would be more efficient to use the SUR approach than the Ordinary Least-Squares (OLS) one when estimating panel data causality (Zellner, 1962). In addition, Pesaran (2006) argued that substantial biases and size distortions would occur when cross-sectional dependency existed and was ignored. Finally, if we assume that the panel data series have the property of homogeneity, then the heterogeneity among countries showing country-specific characteristics will not be captured (Breitung, 2005).

In this contribution, therefore, we examine firstly the panel data to find out whether the characteristics of cross-sectional dependency and slope heterogeneity among countries exist. If so, then the approach proposed by Kónya (2006) is the most appropriate one in analyzing panel data and Granger causality between variables considered in this paper. To investigate the existence of cross-section dependence we carry out four different tests $\left(\mathrm{LM}, \mathrm{CD}_{\mathrm{lm}}, \mathrm{CD}, \mathrm{LM}_{\mathrm{adj}}\right)$. These test results are reported in Table 1.

\footnotetext{
${ }^{17}$ Fiscal consolidation episodes proposed by Alesina and Ardagna (1998) are computed by the authors.

${ }^{18}$ The IMF's dummy is not available for Greece.
} 
Table 1 Cross-sectional dependency and homogeneity test.

\begin{tabular}{lcccc}
\hline Study & FC(AA) & FC(IMF) & EG & EMP \\
\hline LM (Breusch and Pagan, 1980) & $276.812^{* * *}$ & $214.651^{* * *}$ & $344.780^{* * * *}$ & $305.204^{* * * *}$ \\
CD (Pesaran, 2004) & $14.006^{* * *}$ & $10.691 * * *$ & $12.702^{* * *}$ & $15.893^{* * *}$ \\
$C D_{a d j}$ (Pesaran et al., 2008) & $13.875^{* * *}$ & $11.794 * * *$ & $14.546^{* * *}$ & $13.903^{* * *}$ \\
Swamy (1970) & $657.091^{* * *}$ & $567.815^{* * *}$ & $812.704^{* * *}$ & $709.540^{* * *}$ \\
$\tilde{\Delta}$ & $123.809^{* * *}$ & $146.340^{* * *}$ & $173.365^{* * *}$ & $187.371^{* * *}$ \\
$\tilde{\Delta}_{a d j}$ & $2.129^{* * *}$ & $1.401^{* * *}$ & $3.185^{* * *}$ & $4.609^{* * *}$ \\
\hline
\end{tabular}

Notes: $(*)$ indicates rejection of the null hypothesis at $1 \%$ level of significance.

The data cover the whole sample period from 1980 to 2014. FC(AA), EG, FC(IMF) and EMP denote Alesina and Ardagna's (1998) fiscal consolidation episode, economic growth, IMF's fiscal consolidation episode and employment, respectively.

As shown in Table 1, the null of no cross-sectional dependency across the countries is strongly rejected at the conventional levels of significance, implying that the SUR method is appropriate rather than the country-by-country OLS estimation. This finding implies that a shock occurred in one of the PIIGGS countries tends to be transmitted to other countries and that when a shock occurs in any of them, it, then, would affect the others.

Table 1 also shows the results obtained from the two slope homogeneity tests, Wald and S. Both tests reject the null hypothesis of the slope homogeneity hypothesis, supporting the country specific heterogeneity. The rejection of slope homogeneity implies that the panel causality analysis by imposing homogeneity restriction on the variable may result in misleading inferences. In this respect, the panel causality analysis based on estimating a panel vector autoregression and/or panel vector error correction model rely on the generalized method of moments; and the pooled ordinary least square estimator is not a proper approach in detecting causal linkages between fiscal consolidation-economic growth and-employment in the PIIGGS countries. As highlighted earlier, it is important to implement both cross-sectional dependence tests and slope heterogeneity tests prior to analyzing panel data Granger causality. The results significantly reject the null hypothesis and indicate that not only do these fiscal consolidation episodes influence the variable of economic growth and employment in each country but also that the regression error terms for countries also influence each other.

Since it is likely that the results obtained from the causality test are sensitive to the lag structure, determining the optimal lag length(s) has crucially important implications for the robustness of our findings. Thereby, prior to embarking on the econometric estimation, it is essential to specify the number of lags. ${ }^{19}$ For a relatively large panel, equation and variable with varying lag structure would lead to an increase in the computational burden substantially. As pointed out by Kónya (2006), the selection of the optimal lag structure is highly important, because the causality test results depend on this.

To determine the optimal lag structure, we follow Kónya's (2006) approach in which maximum lags are allowed to vary across variables, but remain the same across equations. We estimate the system for each possible pair of $l y_{1}, l x_{2}, l y_{2}$ and $l x_{2}$ by assuming 1 to 4 lags and then choose the combinations which minimize the Schwartz Bayesian information criterion.

The existence of the cross-sectional dependency and the heterogeneity across the PIIGGS countries support the evidence regarding the suitability of the bootstrap panel causality approach. In order to save space, the summary of the bootstrap panel causality analysis is presented in Table $2 .^{20}$

\footnotetext{
${ }^{19}$ See Table 2 of Appendix A for the lag selection procedure.

${ }^{20}$ The details of panel Granger causality tests are reported in Appendix C tables 1-4.
} 
Table 2 Summary of panel causality analysis.

\begin{tabular}{|c|c|c|c|}
\hline \multirow{2}{*}{$\begin{array}{l}\text { Direction } \\
\text { of Granger causality }\end{array}$} & \multirow{2}{*}{ PIIGGS Country } & \multicolumn{2}{|c|}{ Granger causality exists } \\
\hline & & Yes / No & $\begin{array}{c}\text { Significance and the sign } \\
\text { of causality }\end{array}$ \\
\hline $\mathrm{FC}(\mathrm{AA}) \rightarrow \mathrm{EG}$ & $\begin{array}{l}\text { Portugal, Ireland, Italy, Greece, Great Britain, } \\
\text { Spain }\end{array}$ & No & Insignificant \\
\hline $\mathrm{EG} \rightarrow \mathrm{FC}(\mathrm{AA})$ & Ireland, Greece, Spain & Yes & Significant and negative \\
\hline $\mathrm{FC}(\mathrm{IMF}) \rightarrow \mathrm{EG}$ & $\begin{array}{l}\text { Portugal, Ireland, Italy, Greece, Great Britain, } \\
\text { Spain }\end{array}$ & No & Insignificant \\
\hline $\mathrm{EG} \rightarrow \mathrm{FC}(\mathrm{IMF})$ & $\begin{array}{l}\text { Portugal, Ireland, Italy, Greece, Great Britain, } \\
\text { Spain }\end{array}$ & No & Insignificant \\
\hline $\mathrm{FC}(\mathrm{AA}) \rightarrow \mathrm{EMP}$ & Portugal & Yes & Significant and negative \\
\hline $\mathrm{EMP} \rightarrow \mathrm{FC}(\mathrm{AA})$ & Portugal & Yes & Significant and negative \\
\hline \multirow[t]{2}{*}{$\mathrm{FC}(\mathrm{IMF}) \rightarrow \mathrm{EMP}$} & Italy & Yes & Significant and negative \\
\hline & Great Britain & Yes & Significant and positive \\
\hline \multirow[t]{2}{*}{$\mathrm{EMP} \rightarrow \mathrm{FC}(\mathrm{IMF})$} & Portugal & Yes & Significant and positive \\
\hline & Spain & Yes & Significant and negative \\
\hline
\end{tabular}

Notes: FC(AA), EG, FC(IMF) and EMP denote Alesina and Ardagna's (1998) fiscal consolidation episode, economic growth, IMF's fiscal consolidation episode and employment, respectively. The IMF's dummy is not available for Greece.

' $\rightarrow$ ' represents Granger causal direction.

Several interesting aspects need to be noted from Table 2. First, regarding the direction of FC(AA) and FC(IMF) to economic growth (EG), we do not find any significant relationship in the countries under consideration. Second, we obtain a significant as well as negative one-way Granger causality running from FC(AA) to employment only for Portugal. As for the direction of FC(IMF) to employment, we find a significant and negative relationship only for Italy. On the other hand, there is a significant and positive one-way Granger causality running from FC(IMF) to employment for Great Britain. Overall, our empirical findings provide no evidence indicating that fiscal consolidation positively affects economic growth for PIIGGS countries. Our findings also confirm that outside Italy and Portugal, in all other countries fiscal consolidation adversely affect employment.

Based on all these empirical findings, we can infer that fiscal consolidation episodes in the PIIGGS countries do not support the validity of the expansionary fiscal contraction hypothesis proposed by Giavazzi and Pagano (1990), and some others (Alesina and Perotti, 1995, 1997; Alesina and Ardagna, 1998, 2010; Giavazzi et al., 2000). Quite the contrary, our findings tend to support the Keynesian view that argues that fiscal consolidation reduces growth as well as employment. These findings may be justified as follows: contractionary fiscal policies aiming to provide fiscal consolidation in these countries leads to a reduction in aggregate demand. Reduction in aggregate demand results in weakening both growth and employment.

\section{SUMMARY AND CONCLUSIONS}

In this paper, we attempt to examine empirically the possible existence of Granger causal interrelationship between fiscal consolidation and growth, as well as between fiscal consolidation and employment, for a panel of the PIIGGS countries that were made up of the European's most affected crisis-countries: Portugal, Ireland, Italy, Greece, Great Britain, and Spain. To do so, first we identify fiscal episodes by replicating Alesina and Ardagna's (1998) and the IMF's approaches, and then we employ the Bootstrap Granger causality test proposed by Kónya (2006) on annual panel data for the period 1980-2014. 
Our empirical results provide no evidence, corroborating the validity of the expansionary fiscal contraction hypothesis that argues fiscal consolidation promotes growth and employment even in the short run. Conversely, the results, to a large extent, tend to support the conventional Keynesian view that argues that fiscal consolidation negatively affects both growth and employment in the short run.

The results confirm that there exists no strong evidence supporting the view that fiscal consolidation episodes are an important determinant of economic growth and employment in the PIIGGS countries. This result may be justified on the basis of the development level of the sample countries. All the countries considered in this paper are developed countries. So, in these countries, different from developing ones, opportunities generating further government revenue through, for example, revenue mobilization or reducing public spending through efficiency increases, are highly limited. In such circumstances, fiscal consolidation policies in these countries may have resulted in a reduction of aggregate demand, leading to decreases in growth and employment.

In conclusion, the fiscal consolidation arguably needed to improve the structural balances, along with reductions in the debt-to-GDP ratio in the countries analyzed, are less likely to generate a favorable growth and employment environment as far as the study period considered in this contribution. 


\section{REFERENCES}

Afonso, A., Jalles, J.T. (2012): Measuring the success of fiscal consolidations, in: Applied Financial Economics, 22, 1053-1061.

Afonso, A., Nickel, C., Rother, P.C. (2006): Fiscal consolidations in the central and eastern European countries, in: Review of World Economics, 142, 402-421.

Alesina, A., Ardagna, S. (2009): Large changes in fiscal policy: taxes vs spending' as cited in Fatas (op.cit) and Alesina, A., fiscal adjustments: lessons from history, Harvard University.

Alesina, A., Ardagna, S., Tavares, J. T. (1998): The political economy of fiscal adjustments, in: Brookings Papers on Economic Activity, 29(1), 197-266.

Alesina, A., Ardagna, S. (1998): Tales of fiscal adjustment, in: Economic Policy, 27, 487-545.

Alesina, A., Ardagna, S. (2013): The design of fiscal adjustments, in: Tax Policy and the Economy, 27(1), 19-68.

Alesina, A., Ardagna, S. (2010): Large changes in fiscal policy: taxes versus spending, in Brown, J.R. (Ed.), in: Tax Policy and the Economy, 24(1), 35-68.

Alesina, A., Perotti, R. (1996): Reducing budget deficits, in: Swedish Economic Policy Review, 3(1), 113-134.

Alesina, A., Perotti, R. (1995): Fiscal expansions and fiscal adjustments in OECD countries, in: Economic Policy, 10(21), 205-248.

Alesina, A., Perotti, R. (1997): Fiscal adjustments in OECD countries: composition and macroeconomic effects, IMF Staff Papers, 44, 210-248.

Alesina, A., Perotti, R. (1998): Economic risk and political risk in fiscal unions, in: Economic Journal, 108(449), 989-1008.

Alesina, A., Ardagna, S., Perotti, R., Schiantarelli, F. (2002): Fiscal policy, profits, and investment, in: American Economic Review, 92, 571-589.

Almeida, V., Castro, G., Felix, R.M., Jose, F.M. (2011): Fiscal consolidation in a small euro area economy, in: Banco de Portugal Economics and Research Department Working Paper Series, No: 5.

Arestis, P., Sawyer, M. (1998): Keynesian economic policies for the new millennium, in: The Economic Journal, 108, 181-195.

Arestis, P. (2011): Fiscal policy is still an effective instrument of macroeconomic policy, in: Panoeconomicus, 58(2), 143-156.

Arestis, P. (2012): Fiscal policy: A strong macroeconomic role, in: Review of Keynesian Economics, 1(1), 93-108. 
Ardagna, S. (2004): Fiscal stabilizations: when do they work and why, in: European Economic Review, 48, 1047-1074.

Arin, K. P., Chmelarova, V. F., Eberhard, W, A. (2011): Why are corrupt countries less successful in consolidating their budgets?, in: Journal of Public Economics, 95, 521-30.

Arin, P, K., Kuhlenkasper, T., Nandialath, M. A. (2015): Critical thresholds for budget consolidations: a semi-parametric approach, in: Applied Economics Letters, 22(16), 12931297.

Baldacci, E., Benedict, C., Gupta, S., Mulas-Granados, C. (2004): Persistence of fiscal adjustments and expenditure composition in low-income countries, in: Gupta, S., Clements B., Inchauste, G. (Eds.), Helping countries develop: the role of fiscal policy, International Monetary Fund, Washington DC, 48-66.

Banerjee, R. N., Zampolli, F. (2016): What drives the short-run costs of fiscal consolidation? evidence from OECD countries, BIS Working Papers, No: 553.

Barro, R. J., Redlick, C. J. (2009): Macroeconomic effects from government purchases and taxes, NBER Working Paper, No: 15369.

Baxter, M., King, R. G. (1993): Fiscal policy in general equilibrium, in: The American Economic Review, 83(3), 315-334.

Bhattacharya, R., Mukherjee, S. (2013): Non-keynesian effects of fiscal policy in OECD economies: an empirical study, in: Applied Economics, 45(29), 4122-4136.

Blanchard, O., Perotti, R. (2002): An empirical characterization of the dynamic effects of changes in government spending and taxes on output, in: Quarterly Journal of Economics, 117, 1329-1368.

Breitung, J. (2005): A parametric approach to the estimation of cointegration vectors in panel data, in: Econometric Reviews, 24(2), 151-173.

Breusch, T.S., Pagan, A. (1980): The lagrange multiplier test and its application to model specifications in econometrics, in: Reviews of Economics Studies, 47, 239-253.

Briotti, M.G. (2002): Fiscal consolidation in EU countries in the nineties: new facts and policy implications, VI. International Conference in Economics, September 11th-14th, Ankara, Turkey, 1-52.

Brückner, M., Pappa, E. (2012): Fiscal expansions, unemployment, and labour force participation: theory and evidence, in: International Economic Review, 53(1), 205-228.

Chowdhury, A., Islam, L. (2012): The debate on expansionary fiscal consolidation: how robust is the evidence?, in: The Economic and Labour Relations Review, 23(3), 13-38.

Cimadomo, J., Bénassy-Quéré, A. (2012): Changing patterns of fiscal policy multipliers in Germany, the UK and the US, in: Journal of Macroeconomics, 34(3), 845-873. 
Coenen, G., Matthias, M., Straub, R. (2008): Fiscal consolidation in the euro area: long-run benefits and short-run costs, ECB Working Paper No. 902.

Cogan, J.F., Taylor, J. B., Wieland, V., Wolters, M. H. (2013): Fiscal consolidation strategy, in: Journal of Economic Dynamics and Control, 37(2), 404-421.

Devries, P, Guajardo, J., Leigh, D., Pescatori, A. (2011): A new action-based data set of fiscal consolidation, IMF Working Paper, No: 11/128.

Escudero, V., Mourelo, E.L. (2017): The employment effect of changes in the composition of fiscal consolidations, in: International Review of Applied Economics, 31(1), 45-68.

Feldstein, M. (1982): Government deficits and aggregate demand, in: Journal of Monetary Economics, 9(1), 1-20.

Giavazzi, F., Pagano, M. (1996): Non-Keynesian effects of fiscal policy changes: international evidence and the Swedish experience, in: Swedish Economic Policy Review, 3, 67-103.

Giavazzi, F., Pagano, M. (1990): Can severe fiscal contractions be expansionary? tales of two small European countries, in: NBER Chapters in: NBER Macroeconomics Annual, 75-122.

Giavazzi, F., Jappelli. T., Pagano, M. (2000): Searching for non-linear effects of fiscal policy: evidence for industrial and developing countries, in: European Economic Review, 44, 12691289.

Giordano, R., Momigliano, S., Neri, S., Perotti, R. (2007): The effects of fiscal policy in Italy: evidence from a VAR model, in: European Journal of Political Economy, 23, 707-733.

Giudice, G., Turrini, A., in't Veld, J. (2007): Non-Keynesian fiscal adjustments? A close looks at expansionary fiscal consolidations in the EU, in: Open Economies Review, 18(5), 613-630.

Giudice, G., Turrini, A., Jan, in't V. (2004): Non-Keynesian fiscal consolidation in the EU? ex post evidence an ex ante analysis, CEPR Discussion Paper, No: 4388.

Granger, C. (2003): Some aspects of causal relationships, in: Journal of Econometrics, 112, 6971.

Gupta, S., Baldacci, E, Clements, B., Tiongson, E. R. (2005): What sustains fiscal consolidations in emerging market countries?, in: International Journal of Finance and Economics, 10, 307-321.

Hall, R. E. (2009): By how much does gdp rise if the government buys more output?, in: Brookings Papers on Economic Activity, 2, 183-231.

Hernández de Cos, P., Moral-Benito, E. (2013): What drives a successful fiscal consolidation?, in: Applied Economics Letters, 20, 748-753.

Heylen, F., Everaert, G. (2000): Success and failure of fiscal consolidation in the OECD: a multivariate analysis, in: Public Choice, 105, 103-124. 
IMF. (2014): Can fiscal policies do more for jobs?, International Monetary Fund, October.

IMF. (2010): Will it hurt? macroeconomic effects of fiscal consolidation, Word Economic Outlook, October, Chapter 3, (Washington).

Islam, I., Chowdhury, A. (2010): Fiscal consolidation, growth and employment: What do we know? A commentary in the Vox EU debate development and the crisis, 21 June, available: http://www.voxeu.org/index.php?q=node/5216 [accessed 8 December 2017].

Kolev, G., Matthes, J. (2013): Smart fiscal consolidation: a strategy for achieving sustainable public finances and growth, Centre for European Studies.

Kónya, L. (2006): Exports and growth: granger causality analysis on OECD countries with a panel data approach, in: Economic Modelling, 23(6), 978-992.

Lambertini, L., Tavares, J. (2003): Exchange rates and fiscal adjustments: evidence from the OECD and implications for EMU, Boston College Working Paper No. 576.

Lucke, B. (1999): Expansionary fiscal contractions and equilibrium indeterminacy: a case study for Germany, in: Applied Economics, 31(6), 697-708.

Mati, A., Thornton, J. (2008): The exchange rate and fiscal consolidation episodes in emerging market economies, in: Economics Letters, 100, 115-118.

McDermott, C. J., Wescott, R. F. (1996): An empirical analysis of fiscal adjustments, IMF Staff Papers, 43(4): 725-53.

Monacelli, T., Perotti, R., Trigari, A. (2010): Unemployment fiscal multipliers, in: Journal of Monetary Economics, 97(5), 531-553.

Perotti, R. (1998): The political economy of fiscal consolidations, in: Scandinavian Journal of Economics, 100(1), 367-394.

Perotti, R. (1999): Fiscal policy when things are going badly, in: Quarterly Journal of Economics, $114,1399-1436$.

Pesaran, M. H., Yamagata, T. (2008): Testing slope homogeneity in large panels, in: Journal of Econometrics, 142(1), 50-93.

Pesaran, M. H., Ullah, A., Yamagata, T. (2008): A bias-adjusted LM test of error crosssection independence, in: Econometrics Journal, 11(1), 105-127.

Pesaran, M.H. (2006): Estimation and inference in large heterogeneous panel with a multifactor error structure, in: Econometrica, 74(4), 967-1012.

Pesaran, M.H.(2004): General diagnostic tests for cross section dependence in panels, IZA Discussion Paper, No: 1240. 
Ramey, V. A. (2009): Identifying government spending shocks: it's all in the timing, NBER Working Paper, No. 15464.

Ramey, V. A., Shapiro, M. D. (1998): Costly capital reallocation and the effects of government spending, Carnegie-rochester conference on public policy, 48, 145-194.

Romer, C. D., Romer, D. H. (2010): The macroeconomic effects of tax changes: estimates based on a new measure of fiscal shocks, in: American Economic Review, 100, 763-801.

Swamy, P. A.V.B. (1970): Efficient inference in a random coefficient regression model, in: Econometrica, 38(2), 311-323.

Turrini, A. (2013): Fiscal consolidation and unemployment: does EPL matter?: a look at EU countries, in: Turrini IZA Journal of Labor Policy, 2(8), 1-18.

Verick, S., Islam, I. (2010): The great recession of 2008-2009: causes, consequences and policy responses, IZA Discussion Paper, No: 4934.

Wagschal, U., Wenzelburger, G. (2012): When do governments consolidate? a quantitative comparative analysis of 23 OECD countries (1980-2005), in: Journal of Comparative Policy Analysis: Research and Practice, 14(1), 45-71.

Zellner, A. (1962): An efficient method of estimating seemingly unrelated regressions and tests for aggregation bias, in: Journal of the American Statistical Association, 57, 348-368. 


\section{Appendix A}

Table 1 Descriptive statistics

\begin{tabular}{|c|c|c|c|c|c|c|}
\hline & Portugal & Ireland & Italy & Greece & Great Britain & Spain \\
\hline \multicolumn{7}{|c|}{ GDP Growth Rate } \\
\hline Mean & 1.942 & 4.308 & 1.243 & 0.894 & 2.154 & 2.235 \\
\hline Median & 1.898 & 4.354 & 1.559 & 2.000 & 2.527 & 2.674 \\
\hline Maximum & 7.489 & 10.862 & 4.194 & 5.794 & 5.787 & 5.547 \\
\hline Minimum & -4.028 & -4.565 & -5.482 & -9.132 & -4.327 & -3.573 \\
\hline Std. Dev. & 2.757 & 3.896 & 1.941 & 3.621 & 2.025 & 2.260 \\
\hline Skewness & -0.154 & -0.325 & -1.356 & -0.964 & -1.155 & -0.809 \\
\hline Kurtosis & 2.488 & 2.758 & 5.658 & 3.473 & 4.815 & 3.044 \\
\hline Normality ${ }^{\mathrm{a}}$ & 0.519 & 0.704 & 21.041 & 5.748 & 12.597 & 3.828 \\
\hline$p$-value & 0.771 & 0.702 & 0.000 & 0.056 & 0.001 & 0.147 \\
\hline Sum & 67.993 & 150.782 & 43.526 & 31.311 & 75.424 & 78.256 \\
\hline Sum Sq. Dev. & 258.507 & 516.226 & 128.193 & 445.824 & 139.553 & 173.691 \\
\hline \multicolumn{7}{|c|}{ Employment Rate } \\
\hline Mean & 55.220 & 47.931 & 42.825 & 44.382 & 52.294 & 43.934 \\
\hline Median & 55.900 & 49.800 & 44.200 & 46.400 & 57.500 & 43.600 \\
\hline Maximum & 59.200 & 61.100 & 45.900 & 49.400 & 59.300 & 53.800 \\
\hline Minimum & 47.700 & 0.000 & 27.900 & 0.000 & 0.000 & 37.000 \\
\hline Std. Dev. & 2.974 & 13.198 & 4.537 & 8.162 & 16.344 & 4.772 \\
\hline Skewness & -0.826 & -2.708 & -2.561 & -4.787 & -2.896 & 0.510 \\
\hline Kurtosis & 2.822 & 10.663 & 8.387 & 26.507 & 9.531 & 2.195 \\
\hline Normality $^{\mathrm{a}}$ & 4.028 & 128.444 & 80.594 & 939.597 & 111.153 & 2.464 \\
\hline$p$-value & 0.133 & 0.000 & 0.000 & 0.000 & 0.000 & 0.291 \\
\hline Sum & 1932.700 & 1677.600 & 1498.900 & 1553.400 & 1830.300 & 1537.700 \\
\hline Sum Sq. Dev. & 300.776 & 5922.515 & 700.106 & 2265.210 & 9083.039 & 774.558 \\
\hline \multicolumn{7}{|c|}{ Fiscal Consolidation (Alesina and Ardagna, 1998) } \\
\hline Mean & 0.257 & 0.142 & 0.142 & 0.314 & 0.171 & 0.114 \\
\hline Median & 0.000 & 0.000 & 0.000 & 0.000 & 0.000 & 0.000 \\
\hline Maximum & 1.000 & 1.000 & 1.000 & 1.000 & 1.000 & 1.000 \\
\hline Minimum & 0.000 & 0.000 & 0.000 & 0.000 & 0.000 & 0.000 \\
\hline Std. Dev. & 0.443 & 0.355 & 0.355 & 0.471 & 0.382 & 0.322 \\
\hline Skewness & 1.111 & 2.041 & 2.041 & 0.800 & 1.743 & 2.424 \\
\hline Kurtosis & 2.235 & 5.166 & 5.166 & 1.640 & 4.040 & 6.879 \\
\hline Normality $^{\mathrm{a}}$ & 8.057 & 31.151 & 31.151 & 6.430 & 19.312 & 56.237 \\
\hline$p$-value & 0.017 & 0.000 & 0.000 & 0.040 & 0.000 & 0.000 \\
\hline Sum & 9.000 & 5.000 & 5.000 & 11.000 & 6.000 & 4.000 \\
\hline Sum Sq. Dev. & 6.685 & 4.285 & 4.285 & 7.542 & 4.971 & 3.542 \\
\hline \multicolumn{7}{|c|}{ Fiscal Consolidation (Devries et al., 2011) } \\
\hline Mean & 0.200 & 0.228 & 0.314 & - & 0.228 & 0.400 \\
\hline Median & 0.000 & 0.000 & 0.000 & - & 0.000 & 0.000 \\
\hline Maximum & 1.000 & 1.000 & 1.000 & - & 1.000 & 1.000 \\
\hline Minimum & 0.000 & 0.000 & 0.000 & - & 0.000 & 0.000 \\
\hline Std. Dev. & 0.405 & 0.426 & 0.471 & - & 0.426 & 0.497 \\
\hline Skewness & 1.500 & 1.292 & 0.800 & - & 1.292 & 0.408 \\
\hline Kurtosis & 3.250 & 2.671 & 1.640 & - & 2.671 & 1.166 \\
\hline Normality ${ }^{a}$ & 13.216 & 9.906 & 6.430 & - & 9.906 & 5.873 \\
\hline$p$-value & 0.001 & 0.007 & 0.040 & - & 0.007 & 0.053 \\
\hline Sum & 7.000 & 8.000 & 11.000 & - & 8.000 & 14.000 \\
\hline Sum Sq. Dev. & 5.600 & 6.171 & 7.542 & - & 6.171 & 8.400 \\
\hline No of obs. & 35 & 35 & 35 & - & 35 & 35 \\
\hline
\end{tabular}

a Jarque-Bera normality test. The p-values correspond to the Jarque-Bera normality statistic. The IMF's dummy is not available for Greece. 
Table 2 The lag selection procedure

\begin{tabular}{lcclllllc}
\hline \multirow{2}{*}{ Lags } & \multicolumn{2}{c}{ FC(AA) causes EG } & \multicolumn{2}{c}{ EG causes FC(AA) } & \multicolumn{2}{c}{ FC(AA) causes EMP } & \multicolumn{2}{c}{ EMP causes FC(AA) } \\
\cline { 2 - 8 } & AIC & SBIC & AIC & SBIC & AIC & SBIC & AIC & SBIC \\
\hline 1 & -4.740 & -4.672 & -5.317 & -5.214 & -4.725 & -4.626 & -5.317 & -4.087 \\
2 & $-4.756^{*}$ & $-4.810^{*}$ & -5.610 & -5.655 & -4.781 & -4.285 & -5.017 & -5.770 \\
3 & -4.210 & -4.716 & -5.947 & -5.917 & -4.417 & -4.215 & -4.142 & -5.482 \\
4 & -4.745 & -4.670 & $-6.312^{*}$ & $-6.318^{*}$ & $-4.840^{*}$ & $-4.883^{*}$ & $-5.653^{*}$ & $-5.784^{*}$ \\
\hline Lags & FC(IMF) causes EG & EG causes FC(IMF) & FC(IMF) causes EMP & EMP causes FC(IMF) \\
\hline 1 & -4.017 & -4.528 & -5.130 & -5.180 & $-4.907^{*}$ & $-4.631^{*}$ & -5.417 & -5.282 \\
2 & $-4.144^{*}$ & $-4.907 *$ & -5.210 & -5.147 & -4.716 & -4.288 & -5.216 & -5.528 \\
3 & -4.051 & -4.347 & -5.479 & -4.716 & -4.709 & -4.540 & -5.017 & -5.479 \\
4 & -4.137 & -4.208 & $-5.804^{*}$ & $-5.265^{*}$ & -4.548 & -4.488 & $-5.485^{*}$ & $-5.568^{*}$ \\
\hline
\end{tabular}

Notes: $(*)$ denotes optimal lag selected. FC(AA), EG, FC(IMF) and EMP denote Alesina and Ardagna's (1998) fiscal consolidation episode, economic growth, IMF's fiscal consolidation episode, and employment, respectively. 


\section{Appendix B}

Cross-sectional dependence and slope homogeneity tests.

\section{Cross-sectional dependency tests}

The cross-sectional dependency among countries implies that a shock that affects one country may spill on to other countries. Cross-sectional dependency is the most important issue when dealing with panel data Granger causality across borders. Due to globalization and increasing degree of integration among countries, a shock that occurs within one nation, it also influences other countries, such as the recent European bond crisis, which was felt around the world. Therefore, when we examine the panel data causality between fiscal consolidation, growth rate and employment rate among the PIIGGS countries considered in this work, is necessary to carry out a series of cross-sectional dependence tests.

To test for cross-sectional dependency, Breusch and Pagan (1980) proposed a Lagrange test. Breusch and Pagan's (1980) LM test has been used in many empirical studies to test crosssectional dependency. LM statistics can be calculated using the following panel model:

$\mathrm{y}_{\mathrm{it}}=\alpha_{\mathrm{i}}+\beta_{i}^{\prime} \mathrm{x}_{\mathrm{it}}+\mu_{\mathrm{it}}$

for $i=1,2, \ldots, \mathrm{N} ; \mathrm{t}=1,2, \ldots, \mathrm{T} \quad$,

where $\mathrm{i}$ is the cross section dimension, $\mathrm{t}$ is the time dimension; $y_{i t}$ is the dependent variable, $\mathrm{x}_{\mathrm{it}}$ is $\mathrm{kx} 1$ vector of explanatory variables while, and $\alpha_{\mathrm{i}}$ and $\beta_{\mathrm{i}}$ are the individual intercepts and slope coefficients allowed to differ across states. In the LM test, the null hypothesis of no cross-sectional dependence $\mathrm{H}_{0}: \operatorname{Cov}\left(\mu_{\mathrm{it}}, \mu_{\mathrm{jt}}\right)=0$ for all $\mathrm{t}$ and $\mathrm{i} \neq \mathrm{j}$ is tested against the alternative hypothesis of cross-sectional dependence $\mathrm{H}_{1}$ : Cov $\left(\mu_{\mathrm{it}}, \mu_{\mathrm{jt}}\right) \neq 0$ for at least one pair of $i \neq j$. Breusch and Pagan (1980) developed the following Lagrange multiplier statistic:

$\mathrm{LM}_{\mathrm{BP}}=\mathrm{T} \sum_{i=1}^{N-1} \sum_{j=i+1}^{N} \hat{\rho}_{i j}^{2}$

where $\hat{\rho}_{\mathrm{ij}}^{2}$ is the sample estimate of the pair-wise correlation of the residuals obtained from ordinary least squares (OLS) estimation of Equation (1) for each i. Under the null hypothesis, the LM statistic has an asymptotic chi-square distribution with $\mathrm{N}(\mathrm{N}-1) / 2$ degrees of freedom. Pesaran (2004) indicates that the LM test is only valid when $\mathrm{N}$ is relatively small and $\mathrm{T}$ is sufficiently large. This drawback is tried to be solved by Pesaran (2004) by the following scaled version of the LM test (the so-called CD test):

$\mathrm{CD}=\sqrt{\frac{1}{N(N-1)}} \sum_{i=1}^{N-1} \sum_{j=i+1}^{N}\left(T \hat{\rho}_{i j}^{2}-1\right)$

However, Pesaran et al. (2008) state that while the population average pair-wise correlations are zero, the CD test will have less power. Therefore, they propose a bias-adjusted test that is a modified version of the LM test by using the exact mean and variance of the LM statistic. The bias-adjusted LM statistic is calculated as follows: 
$\mathrm{CD}_{\mathrm{adj}}=\sqrt{\frac{2 T}{N(N-1)}} \sum_{i=1}^{N-1} \sum_{j=i+1}^{N} \hat{\rho}_{i j} \frac{(T-k) \hat{\rho}_{i j}^{2}-u_{T i j}}{\sqrt{v_{T i j}^{2}}}$

where $\mathrm{u}_{\mathrm{Tij}}$ and $\mathrm{v}_{\mathrm{Tij}}^{2}$ are the exact mean and variance of $(\mathrm{T}-\mathrm{k}) \hat{\rho}_{\mathrm{ij}}^{2}$, which are provided by Pesaran et al. (2008). Under the null hypothesis with first $\mathrm{T} \rightarrow \infty$ and then $\mathrm{N} \rightarrow \infty, \mathrm{CD}_{\text {adj }}$ test is asymptotically distributed as standard normal.

\section{Slope homogeneity tests}

When analysing panel data, another issue to consider is the heterogeneity of the estimated coefficients for each individual case in the panel. As indicated by Granger (2003), the strong null hypothesis is that the causality from one variable to another is obtained by imposing the joint restriction of slope homogeneity for the whole panel. In addition, Breitung (2005) also points out that the assumption of homogeneity for the parameters is not able to capture the heterogeneity that may arise due to country specific characteristics.

The standard F-test is the most widely used way to test the null hypothesis of slope homogeneity $\mathrm{H}_{0}: \beta_{i}=\beta$ for all $\mathrm{i}$ against the hypothesis of heterogeneity $\mathrm{H}_{1}: \beta_{i} \neq \beta_{\mathrm{j}}$ for a nonzero fraction of pair-wise slopes for $\mathrm{i} \neq \mathrm{j}$. This requires that the explanatory variables are strictly exogenous and the error variances are homoscedastic. To relax the assumption of homoscedasticity in the F-test, Swamy (1970) developed a slope homogeneity test that examines the dispersion of individual slope estimates from a suitable pooled estimator.

Pesaran and Yamagata (2008) state that both the F-test and Swamy's test require panel data models where $\mathrm{N}$ is relatively small compared to $\mathrm{T}$. Therefore, they propose a standardized version of Swamy's test (hereafter, $\tilde{\Delta}$ test) for testing slope homogeneity in large panels. The $\tilde{\Delta}$ test is valid when $(\mathrm{N}, \mathrm{T}) \rightarrow \infty$ without any restrictions on the relative expansion rates of $\mathrm{N}$ and $\mathrm{T}$ when the error terms are normally distributed. Swamy's statistic can then be modified as:

$\tilde{S}=\sum_{i=1}^{N}\left(\hat{\beta}_{i}-\hat{\beta}_{W F E}\right)^{\prime} \frac{X_{i}^{\prime} M_{\tau} X_{i}}{\hat{\sigma}_{i}^{2}}\left(\hat{\beta}_{i}-\hat{\beta}_{W F E}\right)$

where $\widehat{\beta}_{\mathrm{i}}$ is the pooled OLS estimator; $\widehat{\beta}_{\mathrm{WFE}}$ is the weighted fixed effect pooled estimator of the Equation (1); $\mathrm{M}_{\tau}$ is an identity matrix of order $\mathrm{T}$ and $\widehat{\sigma}_{\mathrm{i}}^{2}$ is the estimator of $\sigma_{\mathrm{i}}^{2}$. Pesaran and Yamagata (2008) further develop the following standardized dispersion statistic:

$\tilde{\Delta}=\sqrt{N}\left(\frac{N^{-1} \tilde{S}-k}{\sqrt{2 k}}\right)$

Under the null hypothesis with the condition of $(\mathrm{N}, \mathrm{T}) \rightarrow \infty$ and so long as $\sqrt{\mathrm{N}} / \mathrm{T} \rightarrow \infty$, and when the error terms are normally distributed, the $\tilde{\Delta}$ test has an asymptotic standard normal distribution. The small sample properties of the $\tilde{\Delta}$ test can be improved when there are normally distributed errors by using the following mean and variance bias adjusted version:

$\tilde{\Delta}_{a d j}=\sqrt{N}\left(\frac{N^{-1} \tilde{S}-E\left(\tilde{Z}_{i t}\right)}{\sqrt{\operatorname{var}\left(\tilde{Z}_{i t}\right)}}\right)$

where the mean $\mathrm{E}\left(\tilde{\mathrm{Z}}_{\mathrm{it}}\right)=\mathrm{k}$, and $\operatorname{var}\left(\tilde{\mathrm{Z}}_{\mathrm{it}}\right)=2 \mathrm{k}(\mathrm{T}-\mathrm{k}-1) /(\mathrm{T}+1)$. 


\section{Appendix C}

Results for panel causality analyses.

Table 1 Results for panel causality (FC indicator: FC(AA))

\begin{tabular}{|c|c|c|c|c|c|c|c|c|c|c|}
\hline \multirow[t]{2}{*}{$\begin{array}{l}\text { PIIGGS } \\
\text { Country }\end{array}$} & \multirow[t]{2}{*}{$\begin{array}{l}\text { Estimated } \\
\text { Coefficient }\end{array}$} & \multirow[t]{2}{*}{$\begin{array}{c}\text { Wald } \\
\text { stat }\end{array}$} & \multicolumn{3}{|c|}{$\begin{array}{c}H_{0}=\text { FC }(\mathrm{AA}) \text { does not cause EG } \\
\text { Bootstrap Critical Values }\end{array}$} & \multirow[t]{2}{*}{$\begin{array}{c}\text { Estimated } \\
\text { Coefficient }\end{array}$} & \multirow[t]{2}{*}{$\begin{array}{c}\text { Wald } \\
\text { stat }\end{array}$} & \multicolumn{3}{|c|}{$\begin{array}{c}H_{0}=\text { EG does not cause FC(AA) } \\
\text { Bootstrap Critical Values }\end{array}$} \\
\hline & & & $1 \%$ & $5 \%$ & $10 \%$ & & & $1 \%$ & $5 \%$ & $10 \%$ \\
\hline Portugal & -0.16273 & 0.82343 & 5.28335 & 5.28335 & 1.75745 & 0.02548 & 1.10740 & 3.96173 & 3.96173 & 2.53041 \\
\hline Ireland & -0.41502 & 0.11022 & 4.77446 & 4.77446 & 2.67026 & -0.03192 & 5.21495 & 4.17111 & 4.17111 & 3.03209 \\
\hline Italy & 0.69450 & 1.76761 & 5.83104 & 5.83104 & 5.67016 & -0.00651 & 0.57135 & 9.15048 & 9.15048 & 1.03839 \\
\hline Greece & -0.55040 & 0.40488 & 4.36091 & 4.36091 & 2.39071 & -0.03028 & 2.06961 & 1.05632 & 1.05632 & 0.98980 \\
\hline Great Britain & 0.50950 & 0.94671 & 5.55818 & 5.55818 & 3.15018 & -0.00541 & 0.29052 & 2.90616 & 2.90616 & 1.78348 \\
\hline Spain & 0.15449 & 0.10612 & 3.04973 & 3.04973 & 2.69261 & -0.05733 & 7.10445 & 5.13075 & 5.13075 & 3.11739 \\
\hline
\end{tabular}

Notes: FC(AA), EG, FC(IMF) and EMP denote Alesina and Ardagna's (1998) fiscal consolidation episode, economic growth, IMF's fiscal consolidation episode and employment, respectively.

Table 2 Results for panel causality (FC indicator: FC(IMF))

\begin{tabular}{|c|c|c|c|c|c|c|c|c|c|c|}
\hline \multirow[t]{2}{*}{$\begin{array}{l}\text { PIIGGS } \\
\text { Country }\end{array}$} & \multirow[t]{2}{*}{$\begin{array}{c}\text { Estimated } \\
\text { Coefficient }\end{array}$} & \multirow[t]{2}{*}{$\begin{array}{c}\text { Wald } \\
\text { stat }\end{array}$} & \multicolumn{3}{|c|}{$\begin{array}{c}H_{0}=\text { FC(IMF) does not cause EG } \\
\text { Bootstrap Critical Values }\end{array}$} & \multirow[t]{2}{*}{$\begin{array}{c}\text { Estimated } \\
\text { Coefficient }\end{array}$} & \multirow[t]{2}{*}{$\begin{array}{l}\text { Wald } \\
\text { stat }\end{array}$} & \multicolumn{3}{|c|}{$\begin{array}{c}H_{0}=\text { EG does not cause FC(IMF) } \\
\text { Bootstrap Critical Values }\end{array}$} \\
\hline & & & $1 \%$ & $5 \%$ & $10 \%$ & & & $1 \%$ & $5 \%$ & $10 \%$ \\
\hline Portugal & -1.07084 & 2.99383 & 7.49234 & 7.49234 & 4.67971 & -0.01088 & 0.25445 & 1.67160 & 1.67160 & 1.29877 \\
\hline Ireland & -1.91644 & 2.64974 & 8.86966 & 8.86966 & 4.77884 & -0.01902 & 1.71556 & 6.42064 & 6.42064 & 5.65493 \\
\hline Italy & -0.48262 & 1.60715 & 4.63235 & 4.63235 & 3.13276 & -0.00788 & 0.84041 & 5.07904 & 5.07904 & 1.98424 \\
\hline Great Britain & -0.02408 & 0.22356 & 4.15428 & 4.15428 & 3.55672 & 0.00635 & 0.59002 & 10.80464 & 10.80464 & 2.91363 \\
\hline Spain & -0.19597 & 0.16044 & 2.05166 & 2.05166 & 1.28434 & -0.02694 & 1.56751 & 7.96429 & 7.96429 & 2.23438 \\
\hline
\end{tabular}

Notes: FC(AA), EG, FC(IMF) and EMP denote Alesina and Ardagna's (1998) fiscal consolidation episode, economic growth, IMF's fiscal consolidation episode, and employment, respectively. The IMF's dummy is not available for Greece and the IMF's fiscal consolidation episode cover time sample (1980-2007). 
Table 3 Results for panel causality (FC indicator: FC(AA))

\begin{tabular}{|c|c|c|c|c|c|c|c|c|c|c|}
\hline \multirow[t]{2}{*}{$\begin{array}{l}\text { PIIGGS } \\
\text { Country }\end{array}$} & \multirow[t]{2}{*}{$\begin{array}{l}\text { Estimated } \\
\text { Coefficient }\end{array}$} & \multirow[t]{2}{*}{$\begin{array}{c}\text { Wald } \\
\text { stat }\end{array}$} & \multicolumn{3}{|c|}{$\begin{array}{c}H_{0}=\text { FC(AA) does not cause EMP } \\
\text { Bootstrap Critical Values }\end{array}$} & \multirow[t]{2}{*}{$\begin{array}{c}\text { Estimated } \\
\text { Coefficient }\end{array}$} & \multirow[t]{2}{*}{$\begin{array}{c}\text { Wald } \\
\text { stat }\end{array}$} & \multicolumn{3}{|c|}{$\begin{array}{c}H_{0}=\text { EMP does not cause FC(AA) } \\
\text { Bootstrap Critical Values }\end{array}$} \\
\hline & & & $1 \%$ & $5 \%$ & $10 \%$ & & & $1 \%$ & $5 \%$ & $10 \%$ \\
\hline Portugal & -1.12831 & 3.76456 & 1.95884 & 1.95884 & 1.07471 & -0.09480 & 15.69032 & 4.26783 & 4.26783 & 2.79196 \\
\hline Ireland & 2.63035 & 0.37999 & 1.08611 & 1.08611 & 0.66134 & -0.00035 & 0.88096 & 1.04179 & 1.04179 & 0.90866 \\
\hline Italy & 0.90295 & 3.06498 & 4.42442 & 4.42442 & 4.23890 & -0.02411 & 4.88737 & 10.26707 & 10.26707 & 8.68227 \\
\hline Greece & -1.51464 & 3.61393 & 4.91311 & 4.91311 & 3.75933 & 0.00972 & 1.16769 & 12.57556 & 12.57556 & 9.68436 \\
\hline Great Britain & -0.84713 & 0.39491 & 3.81916 & 3.81916 & 2.07450 & -0.00077 & 0.41475 & 17.57018 & 17.57018 & 13.63125 \\
\hline Spain & 0.28463 & 0.19138 & 3.14445 & 3.14445 & 2.09511 & -0.00611 & 0.13339 & 3.03614 & 3.03614 & 2.25274 \\
\hline
\end{tabular}

Notes: FC(AA), EG and EMP denote Alesina and Ardagna's (1998) fiscal consolidation episode, economic growth, and employment, respectively.

Table 4 Results for panel causality (FC indicator: FC(IMF))

\begin{tabular}{|c|c|c|c|c|c|c|c|c|c|c|}
\hline \multirow[t]{2}{*}{$\begin{array}{l}\text { PIIGGS } \\
\text { Country }\end{array}$} & \multirow[t]{2}{*}{$\begin{array}{c}\text { Estimated } \\
\text { Coefficient }\end{array}$} & \multirow[t]{2}{*}{$\begin{array}{l}\text { Wald } \\
\text { stat }\end{array}$} & \multicolumn{3}{|c|}{$\begin{array}{c}H_{0}=\text { FC(IMF) does not cause EMP } \\
\text { Bootstrap Critical Values }\end{array}$} & \multirow[t]{2}{*}{$\begin{array}{c}\text { Estimated } \\
\text { Coefficient }\end{array}$} & \multirow[t]{2}{*}{$\begin{array}{c}\text { Wald } \\
\text { stat }\end{array}$} & \multicolumn{3}{|c|}{$\begin{array}{c}H_{0}=\text { EMP does not cause FC(IMF) } \\
\text { Bootstrap Critical Values }\end{array}$} \\
\hline & & & $1 \%$ & $5 \%$ & $10 \%$ & & & $1 \%$ & $5 \%$ & $10 \%$ \\
\hline Portugal & 0.04087 & 0.42470 & 11.68814 & 11.68814 & 6.72849 & 0.05988 & 8.50611 & 4.22395 & 4.22395 & 3.06663 \\
\hline Ireland & -7.24086 & 3.66861 & 5.23620 & 5.23620 & 4.15145 & -0.00178 & 0.17453 & 16.30186 & 16.30186 & 3.71379 \\
\hline Italy & -0.95654 & 4.87490 & 11.60518 & 11.60518 & 3.59538 & 0.00930 & 0.68372 & 1.15398 & 1.15398 & 1.09920 \\
\hline Great Britain & 2.23364 & 2.18145 & 3.49732 & 3.49732 & 2.35241 & -0.00460 & 2.39545 & 11.89618 & 11.89618 & 2.84655 \\
\hline Spain & -0.61144 & 0.82520 & 3.96793 & 3.96793 & 2.13894 & -0.02782 & 3.25413 & 10.55532 & 10.55532 & 3.17384 \\
\hline
\end{tabular}

Notes: EG, FC(IMF) and EMP denote economic growth, IMF's fiscal consolidation episode and employment, respectively. The IMF's dummy is not available for Greece and the IMF's fiscal consolidation episode cover time sample (1980-2007). 